\title{
清涼飲料水中のアセスルファム $\mathrm{K}$ ，サッカリン 及びアスパルテームの同時分析法
}

(昭和 63 年 10 月 31 日受理)

$\begin{array}{lll}\text { 守安貴子* } & \text { 斉藤和夫* } & \text { 中里光男* } \\ \text { 菊池洋子* } & \text { 藤 沼 賢司* } & \text { 二島太一郎* }\end{array}$

\section{Simultaneous Determination of Acesulfame K, Saccharin and Aspartame in Soft Drinks}

\section{Takako Moriyasu, Kazuo Saito, Mitsuo Nakazato, Yoko Kikuchi, Kenji Fujinuma and Taichiro Nishima}

(The Tokyo Metropolitan Research Laboratory of Public Health: 3-24-1, Hyakunin-cho, Shinjuku-ku, Tokyo, Japan)

A rapid convenient method for the simultaneous determination of acesulfame $K(A K)$, saccharin (SA) and aspartame (APM) in soft drinks by high performance liquid chromatography (HPLC) using an ion-pair partition system was developed.

McIlvaine buffer, $\mathrm{pH} 4.5$, and $0.1 \mathrm{M}$ tetrabutylammonium bromide were added to a sample and the solution was passed through Bond Elut $\mathrm{C}_{18}$. The column was washed with water, and the sweeteners were eluted with a mixture of methanol-Mcllvaine buffer, $\mathrm{pH} 3.0(3: 7)$. The eluate was determined by HPLC with a Finepak SIL $\mathrm{C}_{18} \mathrm{~S}$ column and a mobile phase of methanol-water $(2: 8)$ containing tetraethylammonium hydroxide, $\mathrm{pH}$ 4.0. The effluent was monitored with a UV detector at a wavelength of $210 \mathrm{~nm}$. By these procedures, the 3 sweeteners can be well separated and quantitatively determined.

The recoveries of AK, SA and APM from soft drinks spiked at 50 and $200 \mu \mathrm{g} / \mathrm{g}$ were 95 102\%, 93 104\%, 90 102\%, respectively. The detection limits of AK, SA and APM were 10 $\mathrm{mg} / \mathrm{kg}$ of sample.

(Received October 31, 1988)

Key words: アセスルファム $\mathrm{K}$ acesulfame $\mathrm{K}$; サッカリン saccharin; アスパルテーム aspartame；イオンペアークロマトグラフィー ion-pair chromatography; ボンドエルート $\mathrm{C}_{18}$ Bond Elut $\mathrm{C}_{18}$; 清涼飲料水 soft drinks

緒 言

アセスルファム $\mathrm{K}(\mathrm{AK})$ は 1967 年 Clauss らにより 合成されたオキサチアジノンジオキシドのカリウム 塩1), 2)であり，その甘味度は $3 \%$ 水溶液でショ糖の 200 倍を有する新合成甘味料 ${ }^{1)}$ であ。 現在我が国では $\mathrm{AK}$ の使用は認められていないが，すでにイギリス，西ドイ ッをはじめおよそ20 か国で認められており，アメリカ 合衆国においても 1988 年 7 月に卓上甘味料として, ま た飲料，プリンなどの乾燥ベースへの使用が認められる ようになった.

* 東京都立衛生研究所：東京都新宿区百人町 3-24-1
近年, 我が国の輸入食品の増加は著しく, $\mathrm{AK}$ が使用 された食品が輸入される可能性もあるため, 分析対象食 品に, その使用頻度が高いと考えられる清涼飲料水を選 び，あわせてこれらに広く使用されている他の村味料, サッカリン $(\mathrm{SA})$ 及びアスパルテーム $(\mathrm{APM})$ との闹時 分析法について検討した.

$\mathrm{AK}$ の分析法としては薄層クロマトグラフィーํ. 速液体クロマトグラフィー (HPLC) による方法) 7)が報 告されているが, AK, SA 及び APM の組合せによる分 析法は, わずかにグラジェント溶離を用いた HPLCに よる方法 ${ }^{4}$ があるのみである. この方法は分離にグラジ エント溶離を用いているため, 再現性, 定量性の点で, 
やや問題がある. そこで, 著者らは $\mathrm{AK}$ のみならず $\mathrm{SA}$ 及びAPM との分別定量を目的とし，イオンペアーモー ドを用いたアイソクラティックな HPLC の分離条件に ついてカートリッジカラムによる試料の前処理法を導入 して検討したところ，良好な結果が得られたので報告す る.

\section{実験方法}

1. 試

1）混合標準原液：アセスルファム K（純度 $99.4 \%$ へ キスト社製)，サッカリンナトリウム (特級, 和光純薬工 業(株)製)，アスパルテーム(純度 $99.7 \%$ 味の素(株)製) 各々 $100 \mathrm{mg}$ を精ひょうし, 水に溶解して全量 $100 \mathrm{ml}$ としたものを混合標準原液とした。

2) McIlvaine 緩衝液： $0.2 M$ リン酸水素二ナトリウ ム溶液 $20.5 \mathrm{ml}$ または $44.1 \mathrm{ml}$ と， $0.1 M$ クエン酸ナト リウム溶液 $79.5 \mathrm{ml}$ または $55.9 \mathrm{ml}$ を混合し，それぞれ pH 3.0 または pH 4.5 の緩衝液を調製した。

3）前処理用カートリッジカラム：ボンドエルート $\mathrm{C}_{18}$ （アナリティケム社製）充てん量 $1,000 \mathrm{mg}$ を用い た.

4）ボンドェルート $\mathrm{C}_{18}$ 用溶出溶媒：メ夕ノールー Mcllvaine 緩衝液 pH $3.0(3: 7)$ 混液を用いた。

5）イオンペアー試薬：10\% 水酸化テトラエチルア ンモニウム (TEA-OH) 溶液（イオンペアークロマトグラ フィ一用, 東京化成工業(株)製）及び臭化テトラブチル アンモニウム (TBA-Br)（和光純薬工業(株)製）を用い た.

メタノール：HPLC 用を用いた。

その他の試薬は市販特級品を用いた。

\section{2. 装置}

高速液体クロマトグラフ：日本分光工業(株)製 BIP-I 型ポンプ, 同 UVIDEC-VI 型検出器, (株)島津製作所製 C-R3A 型データ処理装置及びレオダイン社製 7125 型 インジェクターにより構成した。

\section{HPLC 条件}

カラム: Finepak SIL $\mathrm{C}_{18} \mathrm{~S}(5 \mu \mathrm{m}, 150 \times 4.6 \mathrm{~mm}$ i. d. $)$ 移動相：TEA-OH を $0.03 M$ 含有したメタノールー水 $(2: 8)$ 混液をリン酸で $\mathrm{pH} 4.0$ に調整した。

流速: $1.0 \mathrm{ml} / \mathrm{min}$

検出波長： $210 \mathrm{~nm}$

注入量： $20 \mu \mathrm{l}$

\section{4. 試験溶液の調製}

試料 $10 \mathrm{~g}$ を $50 \mathrm{ml}$ のメスフラスコにひょう取し， 0.1 $M$ TBA-Br 溶液 $2 \mathrm{ml}$ を加え, Mcllvaine 緩衝液 $\mathrm{pH} 4.5$ で全量を $50 \mathrm{ml}$ としたあのを試料溶液とした。この 10 $\mathrm{ml}$ を, あらかじめメ夕ノール $10 \mathrm{ml}$ 及び $0.01 \mathrm{M}$ TBA-Br 溶液 $10 \mathrm{ml}$ で洗浄したボンドェルート $\mathrm{C}_{18}$ に毎 分 3〜4 $\mathrm{ml}$ の速度で負荷した. 次いで水 $10 \mathrm{ml}$ を用い てカラムを洗浄した後, ボンドエルート $\mathrm{C}_{18}$ 用溶出溶媒
$10 \mathrm{ml}$ で 3 種の甘味料を溶出し, HPLC 用の試験溶液と した。

\section{5. 検量線の作成}

混合標準原液を水で希釈し，2,5,10,50 及び $100 \mu \mathrm{g} /$ $\mathrm{ml}$ の混合標準溶液を調製し，その $20 \mu \mathrm{l}$ をHPLC に付 し，ピーク面積法により検量線を作成した.

\section{結果及び考察}

\section{1. クリーンアップ}

果汁飲料, 乳酸菌飲料, コーヒ一飲料などは固形分を はじめ夾雑物が多いので, フィル夕一処理のみで HPLC に直接注入した場合は多くのピークが長時間にわたって 出現し, さらにカラムの寿命を著しく縮めるおそれもあ る. そこで, これらの問題を解決するために，カートリ ッジ式の前処理カラムを用いたクリーンアップ法につい て検討した。

前処理カラムとして逆相系のセップパック $\dot{C}_{18}$, 充て ん量 $500 \mathrm{mg}$ 及び $1,000 \mathrm{mg}$ のボンドエルート $\mathrm{C}_{18}$ を用 いて，3種の甘味料を同時に効率よく保持あるいは溶離 でき, かつ夾雑物との分離が可能な条件について検討し た.

1）カートリッジカラム及びイオンペアー試薬の選択 $\mathrm{AK}$ と SA は解離定数の大きい強酸性物質であるた め, 3 種のカートリッジカラムにほとんど保持されず, また, 水溶液の $\mathrm{pH}$ を 1 程度に調整しても保持されなか ったことから，イオン抑制法によるカラムへの保持はほ とんど効果がないことが分かった。 そこで $\mathrm{AK} と \mathrm{SA} の$ カラム保持にイオンペアー試薬を用いることとし,

TEA-Br と TBA-Brについて検討した. TEA-Brはいず れのカラムにおいても保持が弱く, AK では試料溶液を 負荷する際に $40 \%$, 洗浄する際に $60 \%$, SA では洗浄す る際に全量溶出した。しかし, TBA-Br の場合には AK 及び SA いずれも全量保持できたのでこれを用いること とした.

一方，ジペプチドの APM はイオンペアー試薬の添加 による効果はほとんど涩められず，むしろ APM の等電 点付近に試料溶液の $\mathrm{pH}$ を調整することによって，力ラ ムへの保持が可能となった。しかし APMは, 試料溶液 $10 \mathrm{ml}$ をカラムに負荷する際に $\mathrm{pH}$ の調整を行っても, 充てん量の少ないセップパック $\mathrm{C}_{18}$ では負荷する際に $19 \%$, 洗浄する際に $22 \%$ 溶出し, 充てん量 $500 \mathrm{mg}$ の ボンドエルート $\mathrm{C}_{18}$ では負荷する際に $4 \%$ ，洗浄する際 に $34 \%$ 溶出した。 しかし, 保持容量の大きい充てん量 $1,000 \mathrm{mg}$ のボンドエルート $\mathrm{C}_{18}$ ではほぼ全量保持する ことができたので，これを前処理カラムとした。

2）試料溶液の $\mathrm{pH}$ 調整

APM は両性物質であるため試料溶液の $\mathrm{pH}$ が APM のカラムへの保持に大きく影響するので， 3 種の甘味料 のカラムへの保持に及ぼす試料溶液の $\mathrm{pH}$ について検討 した。なお，試料溶液としては $50 \mathrm{ml}$ のメスフラスコに 


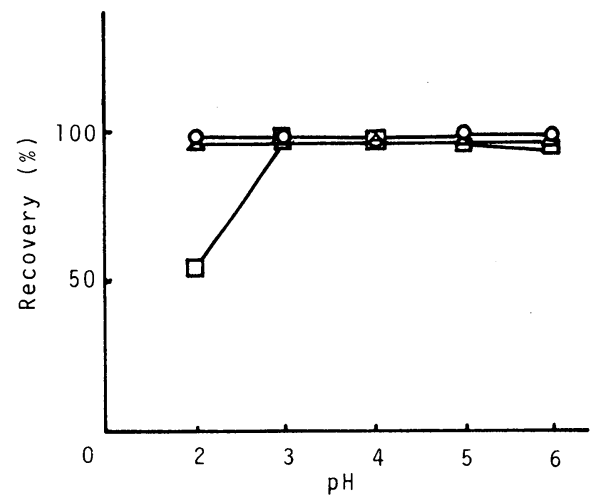

Fig. 1. Effect of the $\mathrm{pH}$ of Mcllvaine buffer for preparation of sample solution on the recoveries of the sweeteners from Bond Elut $\mathrm{C}_{18}(1,000 \mathrm{mg})$

$\bigcirc-\bigcirc$ : acesulfame $K ; \triangle-\triangle$ : saccharin; $\square-\square$ : aspartame

Sweeteners solution $10 \mathrm{ml}$ (each $40 \mu \mathrm{g}$ / $\mathrm{ml}$ ) was added to Bond Elut $\mathrm{C}_{18}(1,000 \mathrm{mg})$.

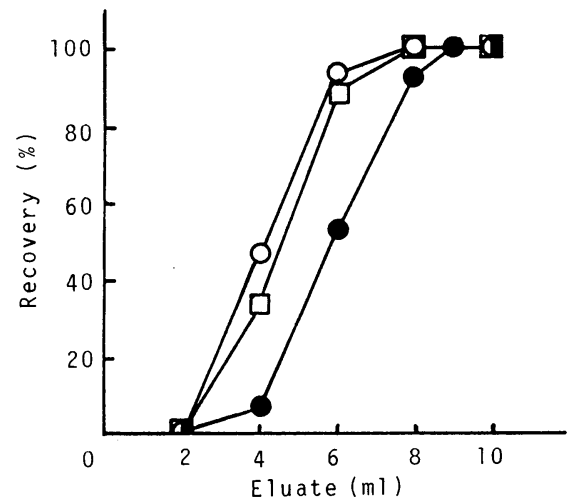

Fig. 2. Elution profiles of the sweeteners from Bond Elut $\mathrm{C}_{18}(1,000 \mathrm{mg})$ $\bigcirc-\bigcirc$ : acesulfame K; $\square-\square$ : aspartame

Eluent was methanol-Mcllvaine buffer pH $3.0(3: 7)$

$200 \mu \mathrm{g} / \mathrm{ml}$ の混合標準溶液 $10 \mathrm{ml}$ 及び $0.1 M$ TBA-Br 溶液 $2 \mathrm{ml}$ を加えた後，pH 2〜6 に調整した Mcllvaine 緩衝液で备々 $50 \mathrm{ml}$ としたものを用い，この $10 \mathrm{ml}$ 充てん量 $1,000 \mathrm{mg}$ のボンドエルート $\mathrm{C}_{18}$ に負荷した. 結果は, Fig. 1 に示したように AK 及び SA は pH 2〜6 の範囲で全量カラムに保持できたことから， AK 及び $\mathrm{SA}$ と $\mathrm{TBA}$ のイオンペアーは幅広い $\mathrm{pH}$ 領域でカラム に保持できることが分かった。一方， APM は pH 4〜5 の範讲で全量保持できたので, 試料溶液の $\mathrm{pH}$ は $\mathrm{McI}$ Ivaine 緩衝液で $\mathrm{pH} 4.5$ 付近に調整することとした。

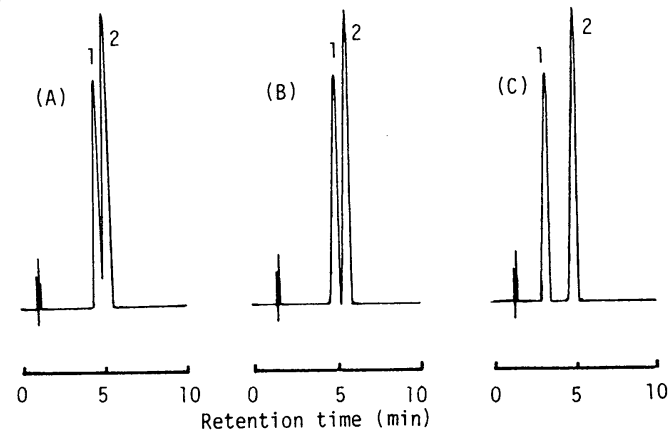

Fig. 3. Effect of ion-pair reagents on separation of acesulfame $\mathrm{K}$ and saccharin 1 , acessulfame $\mathrm{K} ; 2$, saccharin

Operating conditions: column, Finepak SIL $\mathrm{C}_{18} \mathrm{~S}(5 \mu \mathrm{m}, 150 \times 4.6 \mathrm{~mm}$ i. d.); mobile phase, (A) methanol-water $(7: 3)$ containing $0.03 \mathrm{M}$ cetyltrimethylammonium chloride, $\mathrm{pH} 4.0$, (B) methanol-water $(4: 3)$ containing $\quad 0.03 \mathrm{M}$ tetra- $n$-butylammonium bromide, $\mathrm{pH} 4.0,(\mathrm{C})$ methanol-water (2:8) containing $0.03 \mathrm{M}$ tetraethylammonium hydroxide, $\mathrm{pH} 4.0$; flow rate, $1.0 \mathrm{ml}$ $/ \mathrm{min}$; detect, UV $210 \mathrm{~nm}$

\section{3）溶出溶媒の検討}

ボンドェルート $\mathrm{C}_{18}$ からの 3 種の甘味料の溶出条件に ついて検討した。 なお，溶出溶媒の組成は低極性物質が 極力溶出せず, しかも， 3 種の甘味料が $10 \mathrm{ml}$ 前後で溶 出できるメタノール-Mcllvaine 緩衝液の混命比, $3: 7$ に設定した。続いてこの McIlvaine 緩衝液の $\mathrm{pH}$ にい て検討したところ，カラムからの溶出の最適 $\mathrm{pH}$ は $\mathrm{AK}$, $\mathrm{SA}$ 及び APM とも 2.5〜4.0 の範囲であった。しかし, $\mathrm{pH} 4.0$ では APM を完全に溶出させるのに $10 \mathrm{ml}$ 以上: を必要とし， pH 4.0 以下ではより少ない溶出液量で回 収できたため, 溶出溶媒に用いる Mcllvaine 緩衝液の $\mathrm{pH}$ は 3.0 とすることとした。 次に溶出液量について検 討したところ, Fig. 2 に示したように AK 及び APM は

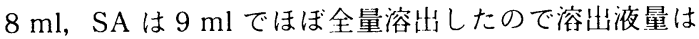
確実性を考慮して $10 \mathrm{ml}$ で行うこととした。

なお，このクリーンアップ条件では，保存料である安 息香酸 (BA), 着色料の一部, 天然战分であるカフェイン (CA)などが同時に溶出したが，パラオキシ安息香酸エ ステル類，クエン酸などの有機酸類，ショ糖などが除去 できることが分かった。

\section{HPLC 条件の検討}

1）イオンペアー試薬の選択

先に述べたように強酸性物質である AK と SA はそ のままではカラムに保持されにくいため, 移動相にイオ ンペアー試薬を添加することによりカラムへの保持能を 


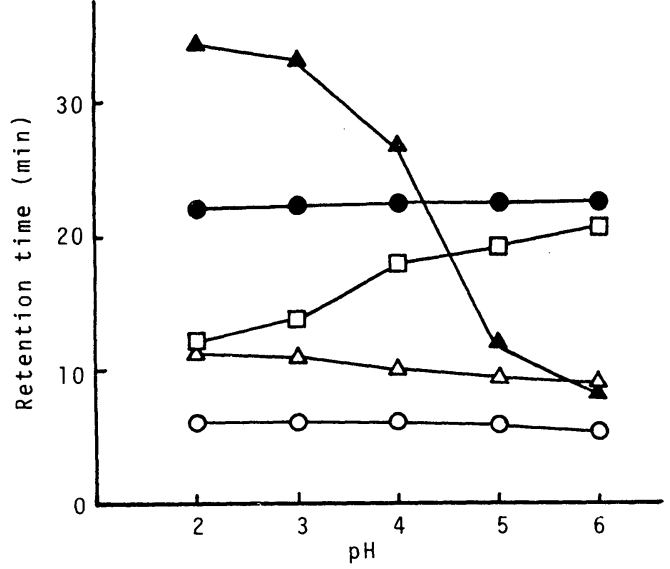

Fig. 4. Effect of the pH of mobile phase on the retention time of the sweeteners, benzoic acid and caffeine

$\bigcirc-\bigcirc$ : acesulfame $K ; \triangle-\triangle$ : saccharin; $\square-\square$ : aspartame; $-\mathbf{O}$ : caffeine; $\boldsymbol{\Delta}-\mathbf{\Delta}$ : benzoic acid

Operating conditions were the same as described in Fig. 3 except for mobile phase. Mobile phase was methanol-water ( $2: 8)$ containing $0.03 \mathrm{M}$ tetraethylammonium hydroxide.

高めることとした. イオンペアー試薬としてはTEA$\mathrm{OH}, \mathrm{TBA}-\mathrm{Br}$ 及び塩化セチルトリメチルアンモニウム (CTA)について検討した. なお，カラムとして Finepak $\mathrm{SIL} \mathrm{C}_{18} \mathrm{~S}$, 移動相にはメタノールー水系を用い, $\mathrm{pH}$ は中 性付近で行った。 結果は Fig. 3 に示したように, CTA を用いた際は AK と SA の保持時間は極めて近似し，両 者の分離は不完全であった。 また, 両者の分離度はイオ ンペア一試薬の分子量が小さいほど大きくなる傾向を示 し, TEA-OH で最も良い分離を得たのでこれを用いる こととした。 なお，移動相に添加する TEA-OH の濃度 は, $0.01 M$ 以下では AK と SA のピークがややブロー ドになる傾向が認められたのでシャープなピークを得る ために， $0.03 M$ とした.

なお，この条件において AK, SA 及び APM を分析し たところ，APM の保持時間は AK と SA に比へ遅かっ た。そこで，APM は pH の影響を強く受けることが考 えられるため, 次に移動相の $\mathrm{pH}$ について検討した.

\section{2) 移動相の $\mathrm{pH}$}

3 種の甘味料の保持時間に及ぼす移動相の $\mathrm{pH}$ の影響 について検討した結果を Fig. 4 に示した. なお, 移動相 のメタノール濃度は $20 \%$ で行うこととし，また，清涼 飲料水に含まれる可能性があり，しかも前処理で 3 種の 甘味料之同時に溶出する BA 及び CA についてああわせ て検討した． $\mathrm{AK}, \mathrm{SA}$ 及び CA の保持時間は $\mathrm{pH} 2 \sim 6$ の 間でほとんよ゙変化は認められなかったが, APM 及び

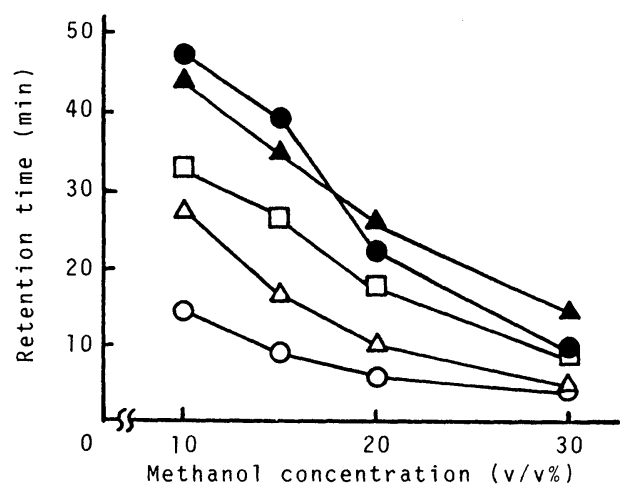

Fig. 5. Effect of the concentrations of methanol on the retention time of the sweeteners, benzoic acid and caffeine

$\bigcirc-\bigcirc$ : acesulfame $K ; \triangle-\triangle$ : saccharin; $\square-\square$ : aspartame; caffeine;

benzoic acid

Operating conditions were the same as described in Fig. 3 except for mobile phase. Mobile phase was methanol-water containing $0.03 \mathrm{M}$ tetraethylammonium hydroxide, $\mathrm{pH} 4.0$.

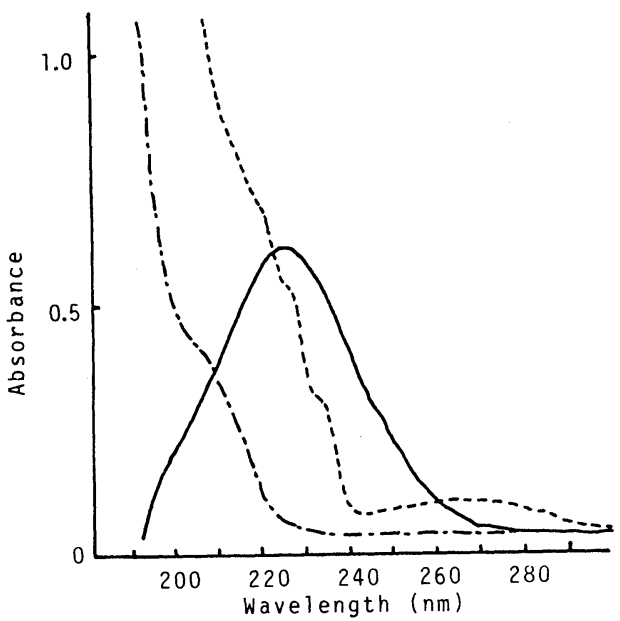

Fig. 6. Absorption spectra of the sweeteners at a concentration of $10 \mu \mathrm{g} / \mathrm{ml}$

- : acesulfame $\mathrm{K} ; \cdots \cdots \ldots$. saccharin; -.-: aspartame

$\mathrm{BA}$ は $\mathrm{pH}$ により大きく変化し, $\mathrm{pH} 2$ では SA と APM, $\mathrm{pH} 4.5$ では $\mathrm{APM}$ と $\mathrm{BA}, \mathrm{pH}$ 5 6 では $\mathrm{SA}$ と $\mathrm{BA}$ との 分離が不十分であった。 そこで，移動相の $\mathrm{pH}$ は 3 種の 甘味料, $\mathrm{BA}$ 及び CA との相互分離が良い $\mathrm{pH} 4$ で行う こととした。

\section{3）移動相の組成}

メタノール濃度による 3 種の甘味料, $\mathrm{BA}$ 及び CA の 
分離, 分析時間への影響について検討した結果を Fig. 5 に示した.メタノール濃度 $10 \sim 15 \mathrm{v} / \mathrm{v} \%$ では 3 種の甘 味料, BA 及び CA の分離が良好であったが, 分析時間 に 40 分以上の時間を要し, $30 \mathrm{v} / \mathrm{v} \%$ では 20 分以内之 短時間で終了したが， APM とCA の分離が不十分であ った. $20 \mathrm{v} / \mathrm{v} \%$ では 3 種の甘味料, BA 及び $\mathrm{CA}$ との分

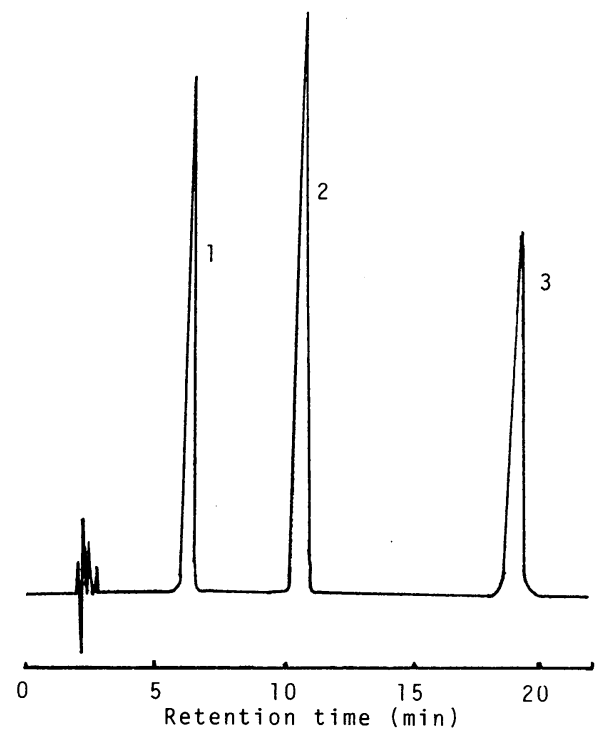

Fig. 7. High performance liquid chromatogram of the sweeteners

1: acesulfame $\mathrm{K} ; 2$ : saccharin; 3 : aspartame

Operating conditions: column, Finepak SIL $\mathrm{C}_{18} \mathrm{~S}(5 \mu \mathrm{m}, 150 \times 4.6 \mathrm{~mm}$ i.d. $)$; mobile phase, methanol-water $(2: 8)$ containing $0.03 M$ tetraethylammonuim hydroxide $\mathrm{pH}$ adjusted 4.0; flow rate, $1.0 \mathrm{ml} / \mathrm{min}$; detect, UV $210 \mathrm{~nm}$
離も良く，しかも分析時間も30 分以内に終了した。 な お, 移動相の溶媒組成については, メ夕ノールー水系の他 にアセトニトリルー水系についても検討したが， $\mathrm{AK}$ 之 SA の分離が不十分であった。

4) 検出波長

3 種の甘味料の紫外部吸収スペクトルは Fig. 6 に示し たとおりで，いずれも同濃度で比較した場合，AK の最
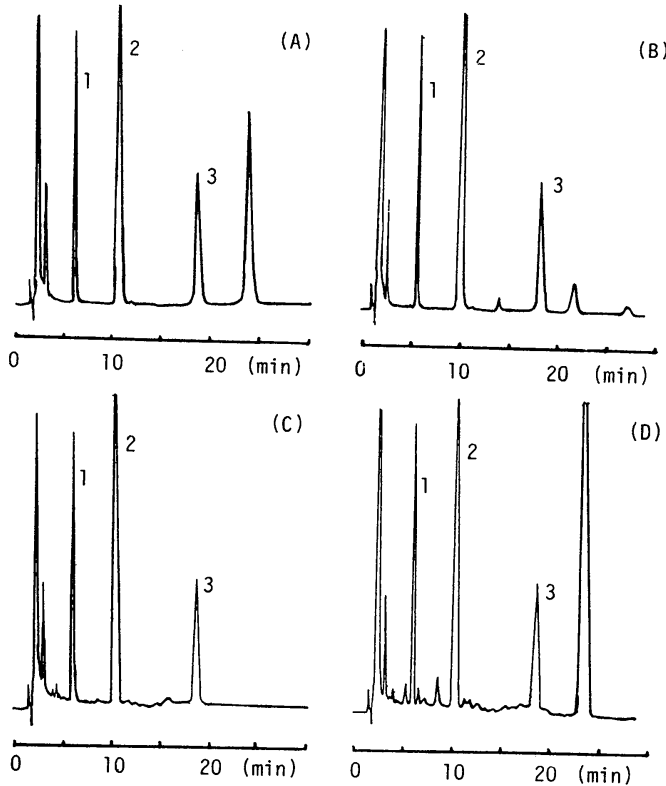

(D)

Fig. 8. High performance liquid chromatograms of sample extracts added the sweeteners

(A): cola; (B): strawberry syrup; (C): apple juice; (D): canned coffee; 1 : acesulfame $\mathrm{K} ; 2$ : saccharin; 3: aspartame

Operating conditions were the same as described in Fig. 7.

Table 1. Recoveries of the Sweeteners from Soft Drinks

\begin{tabular}{|c|c|c|c|c|c|c|}
\hline \multirow{3}{*}{ Sample } & \multicolumn{6}{|c|}{ Recovery* (\%) } \\
\hline & \multicolumn{2}{|c|}{ Acesulfame K } & \multicolumn{2}{|c|}{ Saccharin } & \multicolumn{2}{|c|}{ Aspartame } \\
\hline & $50 \mu \mathrm{g} / \mathrm{g}$ & $200 \mu \mathrm{g} / \mathrm{g}$ & $50 \mu \mathrm{g} / \mathrm{g}$ & $200 \mu \mathrm{g} / \mathrm{g}$ & $50 \mu \mathrm{g} / \mathrm{g}$ & $200 \mu \mathrm{g} / \mathrm{g}$ \\
\hline Carbonated beverage & 98 & 97 & 95 & 95 & 96 & 95 \\
\hline Cola & 97 & 96 & 96 & 93 & 90 & 95 \\
\hline Fruits flavored and colored drinks & 99 & 99 & 99 & 97 & 96 & 102 \\
\hline Apple juice & 102 & 102 & 98 & 97 & 94 & 97 \\
\hline Strawberry syrup & 96 & 95 & 97 & 95 & 93 & 100 \\
\hline Lactic acid bacteria beverage & 101 & 99 & 93 & 93 & 91 & 95 \\
\hline Canned coffee & 101 & 99 & 104 & 97 & 91 & 95 \\
\hline Canned oolong tea & 101 & 99 & 95 & 95 & 95 & 96 \\
\hline
\end{tabular}

* Average of 3 times 
大吸収波長である $227 \mathrm{~nm}$ 付近の吸光度は $\mathrm{AK}$ と $\mathrm{SA}$ がほぼ同じで, APM は1/10 以下であった。 そこで, 3 種の甘味料の同時分析法であることを考慮し, AKと $\mathrm{APM}$ がほぼ同程度の吸光度を示し, SA がその約 2 倍 を示す $210 \mathrm{~nm}$ を検出波長に設定した.

\section{3. 検量線の作成}

$\mathrm{AK}, \mathrm{SA}$ 及び $\mathrm{APM}$ とも $2 \sim 100 \mu \mathrm{g} / \mathrm{ml}$ の範囲で直線 性を示した。なお繰り返し精度は， $50 \mu \mathrm{g} / \mathrm{ml}$ の標準溶 液 $20 \mu \mathrm{l}$ を 7 回繰り返し測定した際，いずれも相対標準 偏差 (RSD) は 1\% 以下であった。標準品のクロマトグ ラムを Fig. 7 に示した。 また，本法における定量限界は 試料中濃度としていずれも $10 \mu \mathrm{g} / \mathrm{g}$ であった。

\section{4. 添加回収実験}

炭酸飲料，コーラ，無果汁飲料，リンゴジュース，イ チゴシロップ, 乳酸菌飲料, 缶入りコーヒー及び缶入り ウーロン茶の 8 種類の清涼飲料水に $\mathrm{AK}, \mathrm{SA}$ 及び $\mathrm{APM}$ が各々 $50 \mu \mathrm{g} / \mathrm{g}, 200 \mu \mathrm{g} / \mathrm{g}$ となるように添加し, 本法に 従って操作し，その結果を Table 1 に示した。 回収率は AK で 95〜 102\%, SA で 93〜 104\%, APM で 90〜 $102 \%$ であり, いずれの清涼飲料水においても 3 種の甘 味料のリテンションタイム付近に妨害となるピークは認 められなかった。 なお, 試料のクロマトグラムの一例を

Fig. 8 に示した.

\section{ま とめ}

HPLC による清涼飲料水中の AK, SA 及び APM の同 時分析法について検討した。

1) 試料にイオンペアー試薬 (TBA-Br) を添加し，ボ
ンドエルート $\mathrm{C}_{18}(1,000 \mathrm{mg})$ で前処理することにより HPLC カラムの保護及び分析時間の短縮を可能とした。

2）移動相にイオンペアー試薬 (TEA-OH) を添加し, $\mathrm{pH}$ を 4.0 に調整することにより, AK, SA 及び APM の 同時分析を可能とした.

3）本法における AK, SA 及び APM の検出限界はい ずれあ $10 \mu \mathrm{g} / \mathrm{g}$ であった.

4） $\mathrm{AK}, \mathrm{SA}$ 及び APM を各々 $50 \mu \mathrm{g} / \mathrm{g}, 200 \mu \mathrm{g} / \mathrm{g}$ と なるように添加した際の回収率は，いずれも $90 \%$ 以上 であった。

謝辞

本研究に当たり, 貴重な資料及び標準品を提供してい ただいた，へキストジャパン株式会社に深謝致します。

文献

1) Hough, C. A. M., Parker, K. J., Vlitos, A. J., "Developments in Sweeteners-1", p. 151 158 (1979), Applied Science Publisers Ltd., London.

2) Rymon, L. G.-W. von: ジャパンフードサイエンス 9, 78〜 82 (1985).

3) Rymon, L.G.-W. von, Brixius, H-Ch.: Z. Lebensm. Unters. Forsch. 168, 212 213 (1979).

4) Zache, U., Gründing, H.: ibid. 184, 503 509 (1987).

5) Veerabhadrarao, M., Narayan, M.S., Kapur, O.: J. Assoc. Off. Anal. Chem. 70, 578 582 (1987).

6) Lawrence, J. F.: Analyst. 112, 879 881 (1987).

7) Großpietsch, H., Hachenberg, H.: Z. Lebensm. Unters. Forsch. 171, 41 43 (1980). 